Review

\title{
Are the Dietary Guidelines for Meat, Fat, Fruit and Vegetable Consumption Appropriate for Environmental Sustainability? A Review of the Literature
}

Christian John Reynolds $^{1,2, *}$, Jonathan David Buckley ${ }^{3}$, Philip Weinstein ${ }^{4}$ and John Boland ${ }^{1}$

1 Centre for Industrial and Applied Mathematics, the Barbara Hardy Institute, University of

South Australia, Mawson Lakes Boulevard, Mawson Lakes, SA 5095, Australia;

E-Mail: john.boland@unisa.edu.au

2 Integrated Sustainability Analysis, University of Sydney, Sydney, 2000, Australia

3 Nutritional Physiology Research Centre, Sansom Institute for Health Research, University of

South Australia, Mawson Lakes Boulevard, Mawson Lakes, SA 5095, Australia;

E-Mail: jon.buckley@unisa.edu.au

4 School of Pharmacy and Medical Sciences, Division of Health Sciences, University of

South Australia, Mawson Lakes Boulevard, Mawson Lakes, SA 5095, Australia;

E-Mail: phil.weinstein@unisa.edu.au

* Author to whom correspondence should be addressed; E-Mail: christian.reynolds@unisa.edu.au; Tel.: +61-400-94-2636.

Received: 1 April 2014; in revised form: 19 May 2014 / Accepted: 5 June 2014 /

Published: 12 June 2014

\begin{abstract}
This paper reviews the current literature around the environmental impacts of dietary recommendations. The focus of the review is on collating evidence relating to environmental impacts of the dietary advice found in the World Health Organisation guidelines, and environmental impact literature: reducing the consumption of fat, reducing the consumption of meat-based protein and animal-based foods, and increasing the consumption of fruit and vegetables. The environmental impact of reducing dietary fat intake is unclear, although reducing consumption of the food category of edible fats and oils appears to have little impact. However most, but not all, studies support environmental benefits of a reduced consumption of animal-based foods and increased consumption of fruit and vegetables. In general, it appears that adhering to dietary guidelines reduces impact on the environment, but further study is required to examine the environmental impacts of animal-based foods, and fruit and vegetable intake in depth.
\end{abstract}


Keywords: environmental impact; diet; food; red meat; animal protein; fat; fruit; vegetables

\section{Introduction}

Food consumption contributes an estimated $20 \%$ to $30 \%$ of the total adverse environmental impact in the Western world [1,2], being linked to soil, air, and water pollution and loss of biodiversity [3-16]. Despite this having been recognised for some time, the idea of altering diet to increase environmental sustainability is a relatively new concept that until the last decade had little real-life implementation $[3,4,17,18]$.

Currently, dietary guidelines in most jurisdictions are mainly used to promote healthy eating to prevent chronic disease [19,20], with environmental, economic, or social impacts of diet considered to be externalities. Typically, as seen in the global dietary guidelines discussed by the World Health Organization (WHO) and the United Nations Food and Agriculture Organization (FAO) [21], the dialogue on environmental benefits is tempered by the focus on health, and the need to provide practical advice that people can follow. Environmental considerations, if mentioned, are relegated to the appendices - as in the current Australian Dietary guidelines [22,23]. Rare exceptions to this trend are the recent publications by the Health Council of the Netherlands [24] and the Nordic Council of Ministers [25] which discuss a healthy diet from an ecological perspective.

Globally there is much debate over what constitutes a healthy diet, how to optimise diet, and how to present this information to the general population [26-33]. There are national and international "healthy" portion sizes, and recommended daily allowances of differing foodstuffs based upon caloric content, cultural, historic and economic factors. Yet many studies express difficulty in finding an individual eating in perfect concordance with global dietary guidelines [21,34-36].

Since the 1960s there has been a marked increase in the variety of dietary guidelines published [37-39]. Concurrently, the global diet has shifted due to the rising global average income, and greater access to cheap, highly processed foodstuffs and animal products, resulting in increasing rates of obesity and chronic disease [40]. The intensification of publication and debate over recommended diets can be seen, in part, as a reaction to this changing global diet and the adverse impacts on health. Yet, as indicated above, discussion around the environmental impacts of recommended dietary guidelines is now only emerging [41].

In this paper we focus on dietary guidelines, excluding nutrient guidelines (such as [42]). The sheer variety of foods that an individual can choose from to obtain the recommended daily nutrients, results in greater complexity with respect to the associated environmental impacts. Due to the complexity we believe that nutrient guidelines are deserving of their own analysis.

In this paper we review the current environmental impact assessment and life cycle analysis (LCA) literature around the environmental impacts of dietary recommendations, focusing on collating the environmental evidence behind three pieces of dietary advice that are debated in current environmental impact assessment and LCA literature, and also presented in the WHO guidelines: reducing the consumption of fat, reducing the consumption of meat-based protein and animal-based foods, and increasing the consumption of fruit and vegetables [21,32,33]. Environmental impacts of dietary 
advice presented in WHO guidelines to reduce sugar consumption have not been evaluated in the LCA literature and was therefore unable to be included in this review. The lack of assessment of the impact of this guideline indicates a gap in the literature that should be addressed in future studies.

\section{Reducing Fats}

Since the 1960s the average global daily consumption of fat has increased by 20 g per person (27\%) [21]. This rise in fat consumption is proposed to be due to an increase in the availability and consumption of cheaper energy-dense, high-fat, nutrients-poor food stuffs [43-46] such as processed snacks, caloric beverages, fast foods, and edible oils and spreadable fats. The increase in fat intake, and associated increase in energy intake, has been blamed for contributing to an epidemic increase in overweight and obesity and associated health conditions, with 1.5 billion people classified as overweight and over 500 million as obese [40,47].

Fats can be understood to be an independent category of food, as well as a nutritional component of a broad range of foodstuffs. Thus, fats can be directly consumed as edible oils and spreads, or indirectly consumed in food sources such as dairy, meat, etc. This dual nature of the dietary availability of fats has meant that dietary and nutrient advice has overlapped in discussing healthy fat consumption levels. As a result most dietary guidelines provide recommendations for total fat consumption, rather than specific recommendations for consumption of fat as edible oils and spreadable fats. The current WHO guidelines recommend that $15 \%-30 \%$ of dietary energy be supplied from fats. However, the actual amount of dietary energy derived from fats is country dependent, with the figure for developed nations being around 20\%-40\% [21,48,49]. This recommendation by the WHO to limit fat consumption is based on recommendations aimed at improving health rather than environmental impacts, and relates to total intake of fat from all sources, including not only foods from the food category of edible fats and oils, but also fat contained as part of the nutrient profile of other foods. In terms of environmental impacts however, because of the assessment methodologies used, it has to date only been possible to estimate the environmental impacts of edible fats and oils as a food category and not to evaluate the independent environmental effects of fats that form part of the composition of other food categories. For example, meat contains fat as part of its nutritional profile, but separate analysis cannot currently be undertaken to estimate the environmental impact of the fat content of the meat independently from the protein and other nutrients as the current methodologies available do not permit this level of analysis. Thus, at present analysis of the environmental impacts of fat is limited to analysis of the food category of edible fats and oils.

Vieux et al. [50] examined the greenhouse gas effects of reducing the consumption of energy-dense, high-fat, nutirent-poor food stuffs, and found that the food category of edible fats contributed $7 \%$ of daily diet-associated greenhouse gas emissions compared to fruit and vegetables at $9 \%$, or meat at $27 \%$. Considering that the French diet sources over $40 \%$ of its energy from fat-type products [49], it can be understood that edible fats do not have a large (nor proportional) environmental impact when compared to fruit, vegetables or meat products. In a subsequent study by these same authors, which also evaluated total dietary fat intake (i.e., nutrient analysis), it was reported that while total dietary fat intake was higher in lower nutritional quality diets, these diets were associated with lower greenhouse gas emissions [51], but this latter study was unable to identify the specific contribution of dietary fat to 
greenhouse gas emissions and the lower greenhouse gas emissions may have been related to nutrients other than fat. One strength of these studies was that they evaluated self-selected diets from a random sample of the French population, and therefore reflect the environmental impacts of the actual diversity of food consumption patterns, but a limitation was that they examined the environmental impacts of different food categories rather than the impacts of individual dietary nutrients. Additional research should examine the proportion of environmental consequences from the intake of indirect fats (as nutrients) as opposed to the food category of fats and oils.

Despite the apparently low environmental impact of fat consumption, it has been proposed that fat intake be reduced to improve health, with a possible mechanism to facilitate this being the introduction of a "fat" tax. However, it has been proposed that such a tax would represent an economic device to raise revenue rather than alter diet [43,45,46,52-57]. Conversely, it has been further suggested that fat taxes could be used to increase prices to reflect the actual social cost of food, including the cost of ameliorating environmental impacts [58-61]. A common criticism of "fat" taxes is that they are regressive - with low-income households being forced pay a greater percentage of their income than higher income households. Furthermore, the environmental impacts of a fat tax have not been well examined, with only Friel et al. [62] providing some discussion on the merits of fat taxes to reduce consumption of GHG intensive goods. In particular, Friel et al. [62] discussed that fat-taxes-though useful — should only be part of a behaviour change tool set, and could also be used to "link health and climate-change agendas".

Thus, the reduction of fat consumption via price mechanisms may produce some monetary and health benefits. However, the environmental impact of a reduction in fat consumption is unclear as methods are only available to model the impact of reduced intake of edible fats and oils as a food category and not the impacts of fats that form a nutritional component of other food groups. However, a reduction of fat consumption via the eating of low fat (or fat removed) foods could result in the removed fat becoming food waste if not used by other industries [63-65]. In turn this waste could produce problematic environmental consequences. Further study of the indirect environmental impacts of a low fat diet is required.

\section{Reducing Meat and Animal-Based Foods}

Since the 1960s, the consumption of animal-based foods has risen throughout the world at the expense of consumption of non-animal-based staple foods such as grains, pulses, and fruits and vegetables [6]. This is due to increased production efficiency of the meat and dairy industries [66-70], higher standards of living and a rising global average income with an increasing demand for meat [71-73]. This is most evident in China with total meat consumption increasing 165\% since 1990, while in Asia as a whole it has increased 30-fold since 1961 [74]. However, there is some evidence that meat consumption in Asia may have peaked, and that these countries may now not be following the developed world's consumption pattern for more meat [71,73,74].

The consumption of meat and animal products offers essential (micro) nutritional security to many who would be otherwise food insecure [75-77]. However, excessive consumption of meat and animal products in some countries, and in some social classes within countries, can lead to excessive intakes of fat (nutrients), which can impact adversely on health [78]. This has led to the recommendation in 
some dietary guidelines [22] to limit meat consumption, in particular processed meat and, for men to reduce their intake of red meat. Even with such recommendations, the FAO is projecting a global yearly consumption of $45 \mathrm{~kg}$ of meat and $95 \mathrm{~kg}$ of dairy per person by the year 2030 [21]. Though this is below the 1997/9 average yearly meat and milk consumption of both industrialised (88 kg, $212 \mathrm{~kg}$ ) and transition (46 kg, $159 \mathrm{~kg}$ ) economies [71], is still above levels that many consider to be sustainable $[74,79,80]$.

The environmental impact of meat and animal product consumption has been the topic of some investigation $[6,67,68,76,79-86]$. It has been found that meat-centric meals generate on average nine times higher greenhouse gas emissions than plant-based equivalents [5], while specific meat-based products such as beef and cheese cause 10-20 times more environmental impact [87-89]. An animal-based diet requires 2.5-5.0 times the energy inputs [7,90-93], 2-3 times the water, 13 times the fertilizer, and 1.4 times the pesticide use per calorie produced compared with a plant-based diet $[7,93,94]$. In European life cycle assessment studies, because of the relatively high meat intake in the typical diet, meat-free scenarios were between $18 \%$ and $31 \%$ lower in greenhouse gas emissions than the average diet $[17,41]$.

Though there is literature suggesting an environmentally friendly diet can be achieved with meat and dairy products present [28], there have been many arguments mounted against meat dominant diets [5,93,95-98]. If animal-based foods are to be part of the diet, the selection of the least environmentally damaging foods is crucial. McMichael et al. [98] modelled a working global yearly meat intake target of no more than $32 \mathrm{~kg}$ per person with no more than $18 \mathrm{~kg}$ per year coming from red meat from ruminants (i.e., cattle, sheep, goats, etc.). This is below the projected intake of $45 \mathrm{~kg}$ of meat for a meat-reduced diet cited in the aforementioned WHO/FAO meat consumption projections.

Besides selecting non-ruminant animals, another way to minimise the impact of animal products is to use farming practices that are suitable to the land type, and select less environmentally damaging feed and fodder [17]. These farming practices (lot-fed compared to grass-fed) can result in pronounced differences of environmental impacts. Studies $[87,99,100]$ have shown this variance to be dependent on the type and geography of the farmed land and the differences can be minimal [101] — grass feeding having a potentially greater environmental impact than lot feeding in arid areas, while in developed nations with temperate climates, lot feeding can have greater impacts depending on the production systems [86].

The larger contribution to the environmental impact of animals that can be altered is the feed used [102-104]. Currently there is a large dependency on cereals and legumes (such as wheat, corn and soy) for animal feed with $37 \%$ of global cereal production being fed to animals [76]. Traditionally farming of these cereals has been resource intensive with a sizeable environmental footprint $[105,106]$. Regardless of the sustainable intensification techniques that are now being implemented, demand for these cereals as animal feed (along with bio fuel production) is currently growing, resulting in global deforestation and biodiversity threats [8]. Switching to alternative sources of animal feed that are less resource intensive might therefore provide a viable method for reducing the environmental impact of animal-based foods. More potentially sustainable alternatives include by-products from other agricultural sectors (such as molasses cake, brewers' grains, vegetable residues and rice husks) [76]. The current level of production from by-product feedstock is limited, despite Fadel [107] finding that there was theoretically enough nutritional content available to provide production for $80 \%$ of global milk 
consumption in 1993. However, this study included processed soymeal as a feed, which Garnett [76] indicates is not a by-product per se, nor can soy meal be claimed to be resource efficient, because industrial soy farming can have many negative environmental consequences [104,108,109].

Fish and seafood consumption provides animal protein from a non-red meat source. Currently, fish and seafood provides more than 4 billion people with approximately $15 \%$ of their intake of animal protein, which equates to a global yearly consumption of approximately $18.6 \mathrm{~kg}$ of fish per person $[21,110]$. This consumption of fish is above the level of population growth, with $57 \%$ of global fish stocks now fully exploited (i.e., at or very close to their maximum sustainable production) and $30 \%$ overexploited [110]. To meet demand and to combat the problems of over fishing wild-caught fish stocks there has been a marked increase in global aquaculture (with much occurring in Asia and Sub-Saharan Africa [111-115]), and a recent World Bank report [116] stated that by 2030, aquaculture will provide close to two thirds of global food fish consumption (186 million tons). With the increasing use of aquaculture, Merino et al. [117] have determined that the fish demand by 2050 will be met, but only if fish resources are managed sustainably and the animal feeds industry reduces its reliance on wild fish. While increasing aquaculture may assist in preventing depletion of wild fish stocks, both wild-caught and aquafarmed fish have substantial environmental impacts, with fish protein being up to 14 times more energy-intensive to produce than a vegetable equivalent [93].

From these statistics, the case can easily be made that reducing the intake of animal protein (including from fish) and dairy foods in the global diet would potentially have considerable impact on reducing environmental effects. However, this is likely to be unpalatable to much of the global population for many cultural, nutritional, and economic reasons [28,118]. Nevertheless, from an environmental perspective the dietary advice to reduce animal based foods is most welcome.

\section{Increasing Fruit and Vegetable Intake}

Fruits and vegetables play a key role in providing a diverse and nutritious diet, with studies showing that adequate consumption of fruits and vegetables reduces the risk of chronic disease [119-121]. However, unlike red meat, the global consumption of fruits and vegetables has persistently been below recommended guidelines [122], with over $77 \%$ of men and women in low- and middle-income countries consuming less than the WHO's minimum recommended $400 \mathrm{~g}$ per capita per day of fruits and vegetables. Consumption of fruits and vegetables for many high income countries is also lower than the WHO's minimum recommended volumes [21,33-35,123].

The environmental impact of fruits and vegetables varies greatly according to the individual type and production method [124-128]. Thus, it is more useful to contrast typical diets with diets high in vegetables and fruit, or high in animal-based foods $[5,98,129,130]$. In these dietary comparisons it has been found that greenhouse gas emissions with diets high in vegetables and fruit are lower than typical diets or diets high in animal-based foods. A number of studies have also reported that vegetarian diets are more environmentally friendly than other dietary patterns [7,93,94,131]. Furthermore, Baumann [132] found that vegan diets produced $23 \%$ less greenhouse gas emissions than the average vegetarian diet. However, it should be noted that from a food security and diet perspective, vegan and vegetarian diets, though lower in environmental impacts, have nutritional risks [133]. Specifically, there is greater potential for the insufficient intake of certain micronutrients $[41,88,134]$. This matters most when diet 
is of a monotonous limited selection, when even a small animal-based food intake could make a critical difference to micronutrient intake [75-77]. Thus the advice for a diet high in fruit and vegetables, with some meat products, has some merit from the food security viewpoint as well as opposed to vegetarian or vegan diets.

While the majority of evidence suggests that an increased intake of fruit and vegetables will reduce environmental impact, there is a small (but growing) literature that suggests a diet low in meat and high in fruits and vegetables is not always low in environmental impact [135]. This is because, in some cases, the quantity of vegetable substitutes eaten to replace animal proteins can contribute similar levels of environmental impacts [50,51], due to the increased quantities of cereals and vegetables for human consumption only slightly outweighing the corresponding decline in the land, water, and resources required to grow feed-cereal previously destined for animals [49]. There needs to be additional modelling to test these claims.

\section{Conclusions}

There are a myriad of possibly sustainable diets, with the components of each part of a diet contributing different volumes of environmental impacts [28]. In this paper we have examined three of the most common pieces of advice found in dietary guidelines. We found evidence of environmental benefits from reducing animal product intake and increasing fruit and vegetable consumption. However, there is also a small (but growing) section of the literature that suggests a diet low in meat and high in fruits and vegetables is not always the most environmentally friendly [135]. Further study is required to examine the veracity and suitability of these claims for the various global diets.

We found little research into the environmental impact of reducing fat in the diet. The most recent study to examine the environmental impact of direct edible fats found that fat currently accounts for less GHG emissions than vegetables, while contributing a larger share of dietary energy. This finding gives weight to the argument that the diets lowest in GHG emissions may not be lowest in fat [51]. Further investigation is needed into the environmental impacts of both direct and indirect fats within contemporary global diets.

Importantly, there is clear evidence that the majority of the global population does not adhere to dietary advice. Our review suggests that further investigation into the environmental benefits of following dietary guidelines in comparison to contemporary reported dietary habits is required. Such evidence would give more strength to the argument for adopting recommended dietary guidelines.

\section{Acknowledgments}

The work described in this paper was supported by internal funding from the University of South Australia. We thank the two anonymous reviewers for their constructive criticism and suggested improvements.

\section{Conflicts of Interest}

The authors declare no conflict of interest. 


\section{References}

1. Tukker, A.; Jansen, B. Environmental Impacts of Products: A Detailed Review of Studies. J. Ind. Ecol. 2006, 10, 159-182.

2. Foley, J.A.; Ramankutty, N.; Brauman, K.A.; Cassidy, E.S.; Gerber, J.S.; Johnston, M.; Mueller, N.D.; O'Connell, C.; Ray, D.K.; West, P.C.; et al. Solutions for a cultivated planet. Nature 2011, 478, 337-342.

3. Gussow, J.D.; Clancy, K.L. Dietary guidelines for sustainability. J. Nutr. Educ. 1986, 18, 1-5.

4. Goodland, R. Environmental sustainability in agriculture: Diet matters. Ecol. Econ. 1997, 23, 189-200.

5. Carlsson-Kanyama, A. Climate change and dietary choices-How can emissions of greenhouse gases from food consumption be reduced? Food Policy 1998, 23, 277-293.

6. Steinfeld, H.; Gerber, P.; Wassenaar, T.; Castel, V.; Rosales, M.; de Haan, C. Livestock's Long Shadow; FAO: Rome, Italy, 2006.

7. Marlow, H.J.; Hayes, W.K.; Soret, S.; Carter, R.L.; Schwab, E.R.; Sabaté, J. Diet and the environment: Does what you eat matter? Am. J. Clin. Nutr. 2009, 89, 1699S-1703S.

8. Lenzen, M.; Moran, D.; Kanemoto, K.; Foran, B.; Lobefaro, L.; Geschke, A. International trade drives biodiversity threats in developing nations. Nature 2012, 486, 109-112.

9. Pinstrup-Andersen, P.; Pandya-Lorch, R. Food security and sustainable use of natural resources: A 2020 vision. Ecol. Econ. 1998, 26, 1-10.

10. Lorek, S.; Spangenberg, J.H. Indicators for environmentally sustainable household consumption. Int. J. Sustain. Dev. 2001, 4, 101-120.

11. Tukker, A.; Goldbohm, R.A.; de Koningb, A.; Verheijden, M.; Kleijn, R.; Wolf, O.; Pérez-Domínguez, I.; Rueda-Cantuche, J.M. Environmental impacts of changes to healthier diets in Europe. Ecol. Econ. 2011, 70, 1776-1788.

12. Jackson, T.; Papathanasopoulou, E. Luxury or 'lock-in'? An exploration of unsustainable consumption in the UK: 1968 to 2000. Ecol. Econ. 2008, 68, 80-95.

13. Druckman, A.; Jackson, T. The carbon footprint of UK households 1990-2004: A socio-economically disaggregated, quasi-multi-regional input-output model. Ecol. Econ. 2009, 68, 2066-2077.

14. Reisch, L.; Scholl, G.; Eberle, U. Discussion Paper 1 on Sustainable Food Consumption; CORPUS: Brussels, Belgium, 2010.

15. Csutora, M. One More Awareness Gap? The Behaviour-Impact Gap Problem. J. Consum. Policy 2012, 35, 145-163.

16. Vetőné Mózner, Z.; Csutora, M. Designing lifestyle-specific food policies based on nutritional requirements and ecological footprints. Sustain. Sci. Pract. Policy 2013, 9, 48-59.

17. Berners-Lee, M.; Hoolohan, C.; Cammack, H.; Hewitt, C.N. The relative greenhouse gas impacts of realistic dietary choices. Energy Policy 2012, 43, 184-190.

18. Joyce, A.; Dixon, S.; Comfort, J.; Hallett, J. Reducing the Environmental Impact of Dietary Choice: Perspectives from a Behavioural and Social Change Approach. J. Environ. Public Health 2012, 2012, 7, doi:10.1155/2012/978672. 
19. Nishida, C.; Uauy, R.; Kumanyika, S.; Shetty, P. The joint WHO/FAO expert consultation on diet, nutrition and the prevention of chronic diseases: Process, product and policy implications. Public Health Nutr. 2004, 7, 245-250.

20. WHO and FAO. Preparation and Use of Food-Based Dietary Guidelines; World Health Organisation: Geneva, Switzerland, 1998.

21. WHO and FAO. Diet, Nutrition and the Prevention of Chronic Diseases; WHO Technical Report Series, No. 916; World Health Organisation: Geneva, Switzerland, 2003.

22. National Health and Medical Research Council. EAT FOR HEALTH Australian Dietary Guidelines Providing the Scientific Evidence for Healthier Australian Diets; National Health and Medical Research Council: Canberra, Australia, 2013.

23. National Health and Medical Research Council. A Review of Evidence to Address Targeted Questions to Inform the Revision of the Australian Dietary Guidelines; Australian Government Department of Health and Ageing: Canberra, Australia, 2011.

24. Health Council of the Netherlands. Guidelines for a Healthy Diet: The Ecological Perspective; Health Council of the Netherlands: The Hague, The Netherlands, 2011.

25. Ministers, N.C.O. Nordic Nutrition Recommendations 2012; Nord: Copenhagen, Denmark, 2014.

26. Rozenbergs, V.; Skrupskis, I.; Skrupska, D.; Rozenberga, E. Food allowance optimization model. In Proceedings of the International Scientific Conference 'Rural En, Jelgava, Latvia, 2013; p. 347.

27. Wilson, N.; Nghiem, N.; Mhurchu, C.N.; Eyles, H.; Baker, M.G.; Blakely, T. Foods and Dietary Patterns That Are Healthy, Low-Cost, and Environmentally Sustainable: A Case Study of Optimization Modeling for New Zealand. PLoS One 2013, 8, e59648.

28. Macdiarmid, J.I.; Kyle, J.; Horgan, G.W.; Loe, J.; Fyfe, C.; Johnstone, A.; McNeill, G. Sustainable diets for the future: Can we contribute to reducing greenhouse gas emissions by eating a healthy diet? Am. J. Clin. Nutr. 2012, 96, 632-639.

29. Shrapnel, B.; Baghurst, K. Lack of nutritional equivalence in the 'meats and alternatives' group of the Australian guide to healthy eating. Nutr. Diet. 2007, 64, 254-260.

30. Rangan, A.M.; Schindeler, S.; Hector, D.J.; Gill, T.P. Assessment of typical food portion sizes consumed among Australian adults. Nutr. Diet. 2009, 66, 227-233.

31. Nestle, M. Food Politics: How the Food Industry Influences Nutrition and Health 2007; University of California Press: London, UK.

32. WHO and FAO. Human Energy Requirements: Report of a Joint FAO/WHO/UNU Expert Consultation; United Nations University: Rome, Italy, 2001.

33. WHO. FAO/WHO Technical Consulation on National Food-Based Dietary Guidelines; WHO: Geneva, Switzerland, 2006.

34. McNaughton, S.A.; Ball, K.; Crawford, D.; Mishra, G.D. An index of diet and eating patterns is a valid measure of diet quality in an Australian population. J. Nutr. 2008, 138, 86-93.

35. Folsom, A.R.; Parker, E.D.; Harnack, L.J. Degree of concordance with DASH diet guidelines and incidence of hypertension and fatal cardiovascular disease. Am. J. Hypertens. 2007, 20, 225-232.

36. MacLennan, R.; Zhang, A. Cuisine: The concept and its health and nutrition implications-global. Asia Pac. J. Clin. Nutr. 2004, 13, 131-135. 
37. Gifford, K.D. Dietary fats, eating guides, and public policy: History, critique, and recommendations. Am. J. Med. 2002, 113, 89-106.

38. Aranceta, J.; Pérez-Rodrigo, C. Recommended dietary reference intakes, nutritional goals and dietary guidelines for fat and fatty acids: A systematic review. Br. J. Nutr. 2012, 107, S8-S22.

39. Truswell, A.S. Evolution of dietary recommendations, goals, and guidelines. Am. J. Clin. Nutr. 1987, 45, 1060-1072.

40. Swinburn, B.A.; Sacks, G.; Hall, K.D.; McPherson, K.; Finegood, D.T.; Moodie, M.L.; Gortmaker, S.L. The global obesity pandemic: Shaped by global drivers and local environments. Lancet 2011, 378, 804-814.

41. Meier, T.; Christen, O. Environmental impacts of dietary recommendations and dietary styles: Germany as an example. Environ. Sci. Technol. 2012, 47, 877-888.

42. Australian Government, Department of Health and Ageing Australia, National Health and Medical Research Council. Nutrient Reference Values for Australia and New Zealand Including Recommended Dietary Intakes; Commonwealth of Australia: Canberra, Australia, 2006.

43. Andrieu, E.; Darmon, N.; Drewnowski, A. Low-cost diets: More energy, fewer nutrients. Eur. J. Clin. Nutr. 2005, 60, 434-436.

44. Drewnowski, A.; Darmon, N.; Briend, A. Replacing fats and sweets with vegetables and fruits-A question of cost. Am. J. Public Health 2004, 94, 1555-1559.

45. Darmon, N.; Briend, A.; Drewnowski, A. Energy-dense diets are associated with lower diet costs: A community study of French adults. Public Health Nutr. 2004, 7, 21-27.

46. Darmon, N.; Ferguson, E.L.; Briend, A. A cost constraint alone has adverse effects on food selection and nutrient density: An analysis of human diets by linear programming. J. Nutr. 2002, 132, 3764-3771.

47. Garnett, T. Food sustainability: Problems, perspectives and solutions. Proc. Nutr. Soc. 2013, 72 , 29-39.

48. Tataranni, P.A.; Ravussin, E. Effect of fat intake on energy balance. Ann. N. Y. Acad. Sci. 1997, 819, 37-43.

49. Srinivasan, C.S.; Irz, X.; Shankar, B. An assessment of the potential consumption impacts of WHO dietary norms in OECD countries. Food Policy 2006, 31, 53-77.

50. Vieux, F.; Darmon, N.; Touazi, D.; Soler, L.G. Greenhouse gas emissions of self-selected individual diets in France: Changing the diet structure or consuming less? Ecol. Econ. 2012, 75, 91-101.

51. Vieux, F.; Soler, L.-G.; Touazi, D.; Darmon, N. High nutritional quality is not associated with low greenhouse gas emissions in self-selected diets of French adults. Am. J. Clin. Nutr. 2013, 97 , 569-583.

52. Caraher, M.; Cowburn, G. Taxing food: Implications for public health nutrition. Public Health Nutr. 2005, 8, 1242-1249.

53. Mytton, O.; Gray, A.; Rayner, M.; Rutter, H. Could targeted food taxes improve health? J. Epidemiol. Community Health 2007, 61, 689-694.

54. Bonnet, C. How to Set up an Effective Food Tax?; Comment on "Food Taxes: A New Holy Grail?”. Int. J. Health Policy Manag. 2013, 1, 233-234. 
55. Wilson, N.; Mansoor, O. Food pricing favours saturated fat consumption: Supermarket data. N. Z. Med. J. 2005, 118, U1338.

56. Wallace, J. Easy on the Oil: Policy Options for a Smaller Waistline and a Lighter Footprint; South Australian Department of Premier and Cabinet: Adelaide, Australia, 2009. Available online: http://www.brass.cf.ac.uk/uploads/Wallace_A70.pdf. (accessed on 10 January 2014).

57. Chouinard, H.H.; Davis, D.; LaFrance, J.; Perloff, J. Fat taxes: Big money for small change. Forum Health Econ. Policy 2007, 10, 1071-1071.

58. Cash, S.B.; Sunding, D.L.; Zilberman, D. Fat taxes and thin subsidies: Prices, diet, and health outcomes. Acta Agric. Scand Sect. C 2005, 2, 167-174.

59. Vinnari, M.; Tapio, P. Sustainability of diets: From concepts to governance. Ecol. Econ. 2012, $74,46-54$.

60. Wirsenius, S.; Hedenus, F.; Mohlin, K. Greenhouse gas taxes on animal food products: Rationale, tax scheme and climate mitigation effects. Clim. Chang. 2011, 108, 159-184.

61. Lombardini, C.; Lankoski, L. Forced Choice Restriction in Promoting Sustainable Food Consumption: Intended and Unintended Effects of the Mandatory Vegetarian Day in Helsinki Schools. J. Consum. Policy 2013, 36, 159-178.

62. Friel, S.; Dangour, A.D.; Garnett, T.; Lock, K.; Chalabi, Z.; Roberts, I.; Butler, A.; Butler, C.D.; Waage, J.; McMichael, A.; et al. Public health benefits of strategies to reduce greenhouse-gas emissions: Food and agriculture. Lancet 2009, 374, 2016-2025.

63. Hall, K.D.; et al. The progressive increase of food waste in America and its environmental impact. PLoS One 2009, 4, e7940.

64. Weiss, T.J. Food Oils and Their Uses; Ellis Horwood Ltd.: Chichester, UK, 1983.

65. Gunstone, F.D. The Chemistry of Oils and Fats: Sources, Composition, Properties, and Uses; CRC Press: Oxford, UK, 2004.

66. Capper, J.L. The environmental impact of beef production in the United States: 1977 Compared with 2007. J. Anim. Sci. 2011, 89, 4249-4261.

67. Cederberg, C.; Mattsson, B. Life cycle assessment of milk production-A comparison of conventional and organic farming. J. Clean. Prod. 2000, 8, 49-60.

68. Cederberg, C.; Stadig, M. System expansion and allocation in life cycle assessment of milk and beef production. Int. J. Life Cycle Assess. 2003, 8, 350-356.

69. Thomassen, M.A.; Dalgaard, R.; Heijungs, R.; de Boer, I. Attributional and consequential LCA of milk production. Int. J. Life Cycle Assess. 2008, 13, 339-349.

70. Vellinga, T.V.; Gerber, P.; Opio, C. Greenhouse gas emissions from global dairy production. Sustain. Dairy Prod. 2013, 2013, 9-30.

71. Bruinsma, J. World Agriculture: Towards 2015/2030: An FAO Perspective; Earthscan: London, UK, 2003.

72. Hallström, E.; Börjesson, P. Meat-consumption statistics: Reliability and discrepancy. Sustain. Sci. Pract. Policy 2013, 9, 37-47.

73. Rivers Cole, J.; McCoskey, S. Does global meat consumption follow an environmental Kuznets curve. Sustain. Sci. Pract. Policy 2013, 9, 26-36.

74. Schwarzera, S.; Witta, R.; Zommers, Z. Growing Greenhouse Gas Emissions Due to Meat Production; UNEP GEAS: Nairobi, Kenya, 2012. 
75. Neumann, C.; Harris, D.M.; Rogers, L.M. Contribution of animal source foods in improving diet quality and function in children in the developing world. Nutr. Res. 2002, 22, 193-220.

76. Garnett, T. Livestock-related greenhouse gas emissions: Impacts and options for policy makers. Environ. Sci. Policy 2009, 12, 491-503.

77. Buttriss, J.; Riley, H. Sustainable diets: Harnessing the nutrition agenda. Food Chem. 2013, 140, 402-407.

78. Hooper, L.; Summerbell, C.D.; Higgins, J.P.T.; Thompson, R.L.; Capps, N.E.; Smith, G.D.; Riemersma, R.A.; Ebrahim, S. Dietary fat intake and prevention of cardiovascular disease: Systematic review. BMJ 2001, 322, 757-763.

79. Heinrich Böll Foundation and Friends of the Earth Europe. MEAT ATLAS Facts and Figures about the Animals We Eat; Möller Druck: Ahrensfelde, Germany, 2014.

80. Ripple, W.J.; Smith, P.; Haberl, H.; Montzka, S.A.; McAlpine, C.; Boucher, D.H. Ruminants, climate change and climate policy. Nat. Clim. Chang. 2014, 4, 2-5.

81. Casey, J.; Holden, N. The relationship between greenhouse gas emissions and the intensity of milk production in Ireland. J. Environ. Qual. 2005, 34, 429-436.

82. Lovett, D.; Shalloo, L.; Dillon, P.; O’Mara, F.P. A systems approach to quantify greenhouse gas fluxes from pastoral dairy production as affected by management regime. Agric. Syst. 2006, 88, 156-179.

83. Basset-Mens, C.; van der Werf, H.M. Scenario-based environmental assessment of farming systems: The case of pig production in France. Agric. Ecosyst. Environ. 2005, 105, 127-144.

84. Eshel, G.; Martin, P.A. Diet, energy, and global warming. Earth Interact. 2006, 10, 1-17.

85. Peters, G.; Wiedemann, S.G.; Rowley, H.V.; Tucker, R.W. Accounting for water use in Australian red meat production. Int. J. Life Cycle Assess. 2010, 15, 311-320.

86. Peters, G.M.; Rowley, H.V.; Wiedemann, S.; Tucker, R.; Short, M.D.; Schulz, M. Red Meat Production in Australia: Life Cycle Assessment and Comparison with Overseas Studies. Environ. Sci. Technol. 2010, 44, 1327-1332.

87. Williams, A. Determining the Environmental Burdens and Resource Use in the Production of Agricultural and Horticultural Commodities; Defra: Cranfield, UK, 2006.

88. Millward, D.J.; Garnett, T. Plenary Lecture 3: Food and the planet: Nutritional dilemmas of greenhouse gas emission reductions through reduced intakes of meat and dairy foods. Proc. Nutr. Soc. 2010, 69, 103-118.

89. Saarinen, M.; Kurppa, S.; Virtanen, Y.; Usva, K.; Mäkelä, J.; Nissinen, A. Life cycle assessment approach to the impact of home-made, ready-to-eat and school lunches on climate and eutrophication. J. Clean. Prod. 2012, 28, 177-186.

90. Horrigan, L.; Lawrence, R.S.; Walker, P. How sustainable agriculture can address the environmental and human health harms of industrial agriculture. Environ. Health Perspect. 2002, $110,445-456$.

91. Pimentel, D.; Pimentel, M. The Future of American Agriculture, in Sustainable Food Systems; Knorr, D., Ed.; Avi Publishers: Westport, CT, USA, 1983; pp. 3-27.

92. Reijnders, L.; Soret, S. Quantification of the environmental impact of different dietary protein choices. Am. J. Clin. Nutr. 2003, 78, 664S-668S. 
93. Hoekstra, A.Y.; Chapagain, A.K. Water footprints of nations: Water use by people as a function of their consumption pattern. Water Resour. Manag. 2007, 21, 35-48.

94. Morgan, E. Fruit and Vegetable Consumption and Waste in Australia; State Government of Victoria, Victorian Health Promotion Foundation: Victoria, Australia, 2009.

95. De Boer, J.; Schösler, H.; Boersema, J.J. Climate change and meat eating: An inconvenient couple? J. Environ. Psychol. 2013, 33, 1-8.

96. Pimentel, D.; Pimentel, M. Sustainability of meat-based and plant-based diets and the environment. Am. J. Clin. Nutr. 2003, 78, 660S-663S.

97. Baroni, L.; Cenci, L.; Tettamanti, M.; Berati, M. Evaluating the environmental impact of various dietary patterns combined with different food production systems. Eur. J. Clin. Nutr. 2007, 61, 279-286.

98. McMichael, A.J.; Powles, J.W.; Butler, C.D.; Uauy, R. Food, livestock production, energy, climate change, and health. Lancet 2007, 370, 1253-1263.

99. Ausubel, J.H.; WernIcK, I.K.; Waggoner, P.E. Peak farmland and the prospect for land sparing. Popul. Dev. Rev. 2013, 38 (Suppl. 1), 221-242.

100. Williams, J.E.; Price, R.J. Impacts of red meat production on biodiversity in Australia: A review and comparison with alternative protein production industries. Anim. Prod. Sci. 2010, 50, 723-747.

101. Chassot, A.; Philipp, A.; Gaillard, G. Oekobilanz-Vergleich von intensivem und extensivem Rindfleischproduktionsverfahren: Fallstudie anhand zweier Fallbeispiele (in German). In Proceedings of Ende der Nische-Beiträge zur 8. Wissenschaftstagung Ökologischer Landbau, Kassel, German, 3 January-3 April 2005.

102. Johnson, J.M.-F.; Franzluebbers, A.J.; Weyers, S.L.; Reicosky, D.C. Agricultural opportunities to mitigate greenhouse gas emissions. Environ. Pollut. 2007, 150, 107-124.

103. Nguyen, T.; van der Werf, H.M.G.; Eugène, M.; Veysset, P.; Devun, J.; Chesneau, G.; Doreau, M. Effects of type of ration and allocation methods on the environmental impacts of beef-production systems. Livest. Sci. 2012, 145, 239-251.

104. WWF. The Growth of Soy: Impacts and Solutions; WWF Internationa: Gland, Switzerland, 2014.

105. Cassman, K.G. Ecological intensification of cereal production systems: Yield potential, soil quality, and precision agriculture. Proc. Natl. Acad. Sci. USA 1999, 96, 5952-5959.

106. Tilman, D.; Cassman, K.G.; Matson, P.A.; Naylor, R.; Polasky, S. Agricultural sustainability and intensive production practices. Nature 2002, 418, 671-677.

107. Fadel, J. Quantitative analyses of selected plant by-product feedstuffs, a global perspective. Anim. Feed Sci. Technol. 1999, 79, 255-268.

108. Nepstad, D.C.; Stickler, C.M.; Almeida, O.T. Globalization of the Amazon soy and beef industries: Opportunities for conservation. Conserv. Biol. 2006, 20, 1595-1603.

109. Fearnside, P.M. Soybean cultivation as a threat to the environment in Brazil. Environ. Conserv. 2001, 28, 23-38.

110. FAO. The State of World Fisheries and Aquaculture; FAO Fisheries and Aquaculture Department: Rome, Italy, 2012.

111. Villasante, S.; Rodríguez-González, D.; Antelo, M.; Rivero-Rodríguez, S.; de Santiago, J.A.; Macho, G. All Fish for China? Ambio 2013, 42, 923-936. 
112. McClanahan, T.; Allison, E.H.; Cinner, J.E. Managing fisheries for human and food security. Fish Fish. 2013, doi:10.1111/faf.12045.

113. Beveridge, M.; Thilsted, S.H.; Phillips, M.J.; Metian, M.; Troell, M.; Hall, S.J. Meeting the food and nutrition needs of the poor: The role of fish and the opportunities and challenges emerging from the rise of aquaculturea. J. Fish Biol. 2013, 83, 1067-1084.

114. Pauly, D.; Chua, T.-E. The overfishing of marine resources: Socioeconomic background in Southeast Asia. Ambio 1988, 17, 200-206.

115. Hilborn, R.; Branch, T.A.; Ernst, B.; Magnusson, A.; Minte-Vera, C.V.; Scheuerell, M.D.; Valero, J.L.; State of the world's fisheries. Annu. Rev. Environ. Resour. 2003, 28, 359.

116. World Bank. Fish to 2030: Prospects for Fisheries and Aquaculture; Publisher: Washington DC, USA, 2013.

117. Merino, G.; Barange, M.; Blanchard, J.L.; Harle, J.; Holmes, R.; Allen, I.; Allison, E.H.; Badjeck, M.C.; Dulvy, N.K.; Holt, J.; Jennings, S.; Mullon, C.; Rodwell, L.D. Can marine fisheries and aquaculture meet fish demand from a growing human population in a changing climate? Glob. Environ. Chang. 2012, 22, 795-806.

118. Lea, E.; Crawford, D.; Worsley, A. Public views of the benefits and barriers to the consumption of a plant-based diet. Eur. J. Clin. Nutr. 2006, 60, 828-837.

119. Boeing, H.; Bechthold, A.; Bub, A.; Ellinger, S.; Haller, D.; Kroke, A.; Leschik-Bonnet, E.; Müller, M.J.; Oberritter, H.; Schulze, M. Critical review: Vegetables and fruit in the prevention of chronic diseases. Eur. J. Nutr. 2012, 51, 637-663.

120. Dauchet, L.; Amouyel, P.; Hercberg, S.; Dallongeville, J. Fruit and vegetable consumption and risk of coronary heart disease: A meta-analysis of cohort studies. J. Nutr. 2006, 136, 2588-2593.

121. Dauchet, L.; Amouyel, P.; Dallongeville, J. Fruit and vegetable consumption and risk of stroke a meta-analysis of cohort studies. Neurology 2005, 65, 1193-1197.

122. Drewnowski, A.; Popkin, B.M. The nutrition transition: New trends in the global diet. Nutr. Rev. 1997, 55, 31-43.

123. Hall, J.N.; Moore, S.; Harper, S.B.; Lynch, J.W. Global variability in fruit and vegetable consumption. Am. J. Prev. Med. 2009, 36, 402-409.

124. Roy, P.; Nei, D.; Orikasa, T.; Xu, Q.; Okadome, H.; Nakamura, N.; Shiina, T. A review of life cycle assessment (LCA) on some food products. J. Food Eng. 2009, 90, 1-10.

125. Renouf, M.A.; Fujita-Dimas, C. Application of LCA in Australia agriculture-A review, In Proceedings of the 8th Life Cycle Conference, Pathways to Greening Global Markets, Sydney, Australia, 16-18 July 2013; ALCAS: Gold Coast, Queensland, Australia.

126. Foster, C.; Green, K.; Bleda, M. Environmental Impacts of Food Production and Consumption. Available online: http:/www.ifr.ac.uk/waste/Reports/DEFRA-Environmental\%20Impacts\%20of \%20Food\%20Production\%20\%20Consumption.pdf (accessed on 9 June 2014).

127. Rab, A.; Fisher, P.; O'Halloran, N. Preliminary Estimation of the Carbon Footprint of the Australian Vegetable Industry; Department of Primary Industries Victoria: Tatura, Australia, 2008.

128. Maraseni, T.N.; Cockfield, G.; Maroulis, J.; Chen, G.; An assessment of greenhouse gas emissions from the Australian vegetables industry. J. Environ. Sci. Health Part B 2010, 45, 578-588.

129. Carlsson-Kanyama, A.; Ekström, M.P.; Shanahan, H. Food and life cycle energy inputs: Consequences of diet and ways to increase efficiency. Ecol. Econ. 2003, 44, 293-307. 
130. Carlsson-Kanyama, A.; González, A.D. Potential contributions of food consumption patterns to climate change. Am. J. Clin. Nutr. 2009, 89, 1704S-1709S.

131. Leitzmann, C. Nutrition ecology: The contribution of vegetarian diets. Am. J. Clin. Nutr. 2003, 78, 657S-659S.

132. Baumann, A. Greenhouse gas emissions associated with different meat-free diets in Sweden. Uppsala University: Uppsala, Sweden, 2013.

133. Worrell, R.; Appleby, M.C. Stewardship of natural resources: Definition, ethical and practical aspects. J. Agric. Environ. Ethics 2000, 12, 263-277.

134. Buttriss, J. Food security through the lens of nutrition. Nutr. Bull. 2013, 38, 254-261.

135. Macdiarmid, J.I. Seasonality and dietary requirements: Will eating seasonal food contribute to health and environmental sustainability? Proc. Nutr. Soc. 2013, doi:10.1017/S0029665113003753.

(C) 2014 by the authors; licensee MDPI, Basel, Switzerland. This article is an open access article distributed under the terms and conditions of the Creative Commons Attribution license (http://creativecommons.org/licenses/by/3.0/). 